\title{
Monoclonal antibody pharmacogenomics in cancer treatment
}

\author{
Shigehiro Yagishita, Akinobu Hamada \\ Division of Molecular Pharmacology, National Cancer Center Research Institute, Chuo-ku, Tokyo 104-0045, Japan.
}

Correspondence to: Dr. Shigehiro Yagishita, Division of Molecular Pharmacology, National Cancer Center Research Institute, 5-1-1, Tsukiji, Chuo-ku, Tokyo 104-0045, Japan. E-mail: syagishi@ncc.go.jp

How to cite this article: Yagishita S, Hamada A. Monoclonal antibody pharmacogenomics in cancer treatment. J Cancer Metastasis Treat 2019;5:75. http://dx.doi.org/10.20517/2394-4722.2019.026

Received: 26 Aug 2019 First Decision: 8 Oct 2019 Revised: 16 Oct 2019 Accepted: 5 Nov 2019 Published: 11 Nov 2019

Science Editor: Godefridus J. Peters Copy Editor: Cai-Hong Wang Production Editor: Tian Zhang

\begin{abstract}
Conventionally, in the pharmacokinetic/pharmacodynamic analysis of small molecule compounds such as cytotoxic anticancer drugs, polymorphism analysis of genes related to absorption, distribution, metabolism, and excretion has been performed in addition to the analyses of blood concentrations of drugs. Such pharmacogenetic factors play an important role in predicting therapeutic effects and adverse events and in the proper use of drugs. With the recent launch of immune checkpoint inhibitors (ICls) and the rapid development of antibody-drug conjugates (ADCs) currently underway, there is no doubt that antibody drugs, which are large molecule compounds, will become key drugs in anticancer drug treatment. However, the pharmacokinetic and pharmacodynamic analysis of antibody drugs is still not sufficient, and further elucidation of factors and mechanisms affecting their dynamics in the human body is necessary. Moreover, the pharmacogenomic factors of antibody drugs have not yet been fully studied. There are many factors that should be clarified, such as factors that regulate the host immune response in $\mathrm{ICl}$ therapy and the effects of ATP-binding cassette transporter and cytochrome P450 on the payload of ADCs. This review provides an outline of antibody drugs in cancer treatment and summarizes the pharmacogenomic factors of antibody drugs known to date.
\end{abstract}

Keywords: Pharmacogenomics, antibody drug, antibody-dependent cellular cytotoxicity, immune checkpoint inhibitor, antibody-drug conjugate 


\section{INTRODUCTION}

An antibody is a humoral immunity factor produced by B cells as a biological defense against foreign antigens in the living body. Antibodies, i.e., immunoglobulins, are composed of a light chain and a heavy chain, and there are 2 types of light chains and five types of heavy chains ${ }^{[1]}$. Immunoglobulins are classified into IgA, IgD, IgE, IgG, and IgM according to heavy chain subtypes, and in human organisms, IgG accounts for $80 \%$. The IgG family includes IgG1, IgG2, IgG3, and IgG4 according to heavy chain subtypes. On the other hand, immunoglobulin receptors are expressed on neutrophils and macrophages and are composed of glycoproteins called Fc receptors. The Fc receptor has subtypes depending on the immunoglobulin to be bound, IgA binds to $\mathrm{F}_{\mathrm{c}} \alpha$ receptor, $\mathrm{IgD}$ binds to $\mathrm{F} \delta \delta$ receptor, $\operatorname{IgE}$ binds to $\mathrm{F} c \varepsilon$ receptor, and $\operatorname{IgG}$ binds to Fcy receptor. The structure of the heavy chain of IgG differs in its binding affinity to Fcy receptors, resulting in specific functional properties for each IgG antibody subtype.

For the immunoglobulin function, four major types of mode of action are known: (1) the neutralizing function by binding of antibody to the antigen; (2) the function of opening the cell membrane by activating complement [complement-derived cellular cytotoxicity (CDC)]; (3) the opsonizing effect taken up by phagocytes through binding of antibody to the antigen; and (4) antibody-dependent cellular cytotoxicity (ADCC) that occurs by binding the antibody to NK cells and releasing cytokines. All currently approved antibody drugs are of the IgG subtype and produce their antitumor effects through these functions.

The application of antibodies to cancer treatment was proposed by the bacteriologist Paul Ehrlich around 1900, but their clinical application became practical since the discovery of monoclonal antibody production technology by the hybridoma of Köhler and Milstein ${ }^{[2]}$ in 1975. Monoclonal antibodies are characterized by having high antigen specificity, producing almost infinite antibodies by hybridomas, and carrying out the same analysis by producing the same antibodies. They also have advantages for anticancer treatment, such as a long half-life, high potency, and low off-target effect.

As a result, monoclonal antibody therapy has increased hope as a "magic bullet". However, the initial development of monoclonal antibodies using mice or rats has been abandoned one after another because of their short half-lives and high immunogenicity. With such a background, several techniques for modifying antibody formulations have been developed such as chimeric antibody that genetically substitutes the highly antigenic constant region of mouse antibody, humanized antibody that substitutes human immunoglobulin except for the complementary-determining region (CDR) site, and fully humanized antibody. Currently, about 26 antibody drugs have been approved against cancer, and the monoclonal antibodies for cancer treatment will be reviewed from a pharmacogenomic perspective.

\section{CANCER THERAPEUTIC ANTIBODY}

As of August 2019, a total of 26 antibody drugs have been approved for cancer treatment by the US Food and Drug Administration (FDA) [Table 1].

The antitumor efficacy of antibody drugs is brought about by any of the 4 functions mentioned above. Of the 26 FDA-approved drugs, 20 are IgG1, one is IgG2, five are IgG4 isotype, and there are no drugs of IgG3 isotype. This is considered to be due to the fact that IgG1, 2, and 4 have a half-life of about 21 days, while IgG3 has a short 7-day half-life. The main features of each IgG subtype are shown in Table 2. ADCC activity, which is dependent on the avidity of IgG and Fc $\gamma R$, is strongest in IgG3, moderate in IgG1, and weak in IgG2 and IgG4 ${ }^{[3]}$. Therefore, a drug that exerts ADCC activity is composed of an IgG1 isotype and an IgG4 or IgG2 isotype for the purpose of neutralizing action or signal inhibition.

Many of the antibody drugs that have been marketed are made to have ADCC activity or ADCC activity and a neutralizing effect as their main antitumor effects. In the 2010s, development of antibody-drug 
Table 1. Therapeutic antibodies for cancer treatment

\begin{tabular}{|c|c|c|c|c|c|c|}
\hline Class & Generic name & Brand name & Subtype & Target & FDA approval & Major indication \\
\hline \multirow[t]{4}{*}{ Chimeric $\mathrm{Ab}$} & Rituximab & Rituxan & $\lg G 1_{\kappa}$ & CD20 & 1997 & CD20+ non-Hodgkin lymphoma \\
\hline & Brentuximab vedotin & Adcetris & $\lg G 1$ & CD30 & 2011 & Hodgkin lymphoma \\
\hline & Cetuximab & Erbitux & $\operatorname{lgG} 1_{\kappa}$ & EGFR & 2004 & Colon cancer \\
\hline & Dinutuximab & Unituxin & $\operatorname{lgG} 1 \kappa$ & GD2 & 2015 & Neuroblastoma \\
\hline \multirow[t]{11}{*}{ Humanized Ab } & Trastuzumab & Herceptin & $\operatorname{lgG} 1_{\kappa}$ & HER2 & 1998 & HER2+ Breast cancer \\
\hline & Gemtuzumab ozogamicin & Mylotarg & $\lg G 4 \kappa$ & CD33 & 2017 & Acute myeloid leukemia \\
\hline & Bevacizumab & Avastin & $\operatorname{lgG} 1_{\kappa}$ & VEGF & 2004 & Colorectal cancer \\
\hline & Mogamulizumab & Poteligio & $\lg G 1_{\kappa}$ & CCR4 & 2018 & CCR4+ Adult T cell leukemia lymphoma \\
\hline & Pertuzumab & Perjeta & $\lg G 1 \kappa$ & HER2 & 2012 & HER2+ Breast cancer \\
\hline & Trastuzumab emtansine & Kadcyla & $\operatorname{lgG} 1_{\kappa}$ & HER2 & 2013 & HER2+ Breast cancer \\
\hline & Obinutuzumab & Gazyva & $\lg G 1_{\kappa}$ & CD20 & 2013 & Chronic lymphatic leukemia \\
\hline & Pembrolizumab & Keytruda & $\lg G 4 \kappa$ & PD-1 & 2014 & Non-small cell lung cancer \\
\hline & Elotuzumab & Empliciti & $\operatorname{lgG} 1_{\kappa}$ & SLAMF7 & 2015 & Multiple myeloma \\
\hline & Atezolizumab & Tecentriq & $\lg G 1 \kappa$ & PD-L1 & 2016 & Urothelial cancer \\
\hline & Inotuzumab ozogamicin & Besponsa & $\lg G 4 \kappa$ & CD22 & 2017 & Acute lymphatic leukemia \\
\hline \multirow[t]{10}{*}{ Human Ab } & Panitumumab & Vectibix & $\lg G 2 \kappa$ & EGFR & 2006 & Colorectal cancer \\
\hline & Ofatumumab & Aezerra & $\lg G 1 \kappa$ & CD20 & 2009 & Chronic lymphatic leukemia \\
\hline & Ipilimumab & Yervoy & $\operatorname{lgG}{ }_{\kappa}$ & CTLA4 & 2011 & Malignant melanoma \\
\hline & Ramucirumab & Cyramza & $\operatorname{lgG1}$ & VEGFR2 & 2014 & Gastric cancer \\
\hline & Nivolumab & Opdivo & $\operatorname{lgG} 4$ & PD-1 & 2015 & Malignant melanoma \\
\hline & Necitumumab & Portrazza & $\lg G 1 \kappa$ & EGFR & 2015 & Non-small cell lung cancer \\
\hline & Daratumumab & Darzalex & $\operatorname{lgG}{ }_{\kappa}$ & CD38 & 2015 & Multiple myeloma \\
\hline & Olaratumab & Lartruvo & $\lg G 1$ & PDGFR & 2016 & Soft tissue sarcoma \\
\hline & Avelumab & Bavencio & $\lg G 1 \lambda$ & PD-L1 & 2017 & Merkel cell carcinoma \\
\hline & Durvalumab & Imfinzi & $\lg G 1_{\kappa}$ & PD-L1 & 2017 & Urothelial cancer \\
\hline Unclassified $\mathrm{Ab}$ & Cemiplimab & Libtayo & $\lg G 4$ & PD-1 & 2018 & Cutaneous squamous cell carcinoma \\
\hline
\end{tabular}

conjugates (ADCs), in which cytotoxic anticancer drugs are bound to antibody drugs, and immune checkpoint inhibitors (ICIs) that cause binding inhibition of immune checkpoint molecules has been rapidly advancing.

\section{PHARMACOGENOMICS OF CANCER THERAPEUTIC ANTIBODIES}

Antibody drugs show anti-tumor effects by binding to antigens in vivo, but because they are proteins with a large molecular weight of about $150 \mathrm{kDa}$, they have complex pharmacokinetic and metabolic pathways that are completely different from small molecule compounds. Small molecule compounds generally have good membrane permeability and a large distribution volume $(\mathrm{Vd})$ because they are distributed in cells ${ }^{[4]}$. Since the effects of metabolism and excretion pathways are large for each drug, many pharmacogenetic studies have been conducted on the effects of polymorphisms of cytochrome $\mathrm{P} 450$ and $\mathrm{ABC}$ transporter on blood concentration levels of drugs. However, in the case of antibody drugs, the Vd is relatively small, they do not undergo metabolism such as by cytochrome P450, and the main elimination route is the digestion of amino acids in cells. For these reasons, they exhibit very different pharmacokinetics from small molecule compounds, and there are still many unknowns. A detailed description of the pharmacokinetics of antibody drugs was given by the critical review of Liming Liu, and this section outlines pharmacogenomic factors that affect the efficacy and pharmacology of antibody drugs ${ }^{[5]}$.

\section{Neonatal Fc receptor}

The neonatal Fc receptor (FcRn) encoded by FCGRT was assumed in the 1960 s to be a receptor that protects IgG from catabolism by Roger Brambell ${ }^{[6,7]}$. After cloning of FcRn by Simister \& Mostov in 1989, analysis of knockout mice by Roopenian \& Akilesh proved its function in $2007^{[8,9]}$. The current understanding of FcRn is that blood circulating IgG is taken up by vascular endothelial cells and monocytes by pinocytosis and receptor-mediated endocytosis. Thereafter, IgG binds to $\mathrm{FcRn}$ in endosomes in an acidic environment ( $\mathrm{pH}$ 
Table 2. Characteristics of IgG isotypes

\begin{tabular}{lcccc}
\hline Heavy chain subtype & Isotype & ADCC activity & CDC activity & Half-life (days) \\
\hline$\gamma 1$ & $\lg G 1$ & ++ & ++ & 21 \\
$\gamma 2$ & $\lg G 2$ & + & + & 20 \\
$\gamma 3$ & $\lg G 3$ & +++ & +++ & 7 \\
$\gamma 4$ & $\operatorname{lgG} 4$ & + & - & 21 \\
\hline
\end{tabular}

ADCC: antibody-dependent cellular cytotoxicity; CDC: complement-derived cellular cytotoxicity

$<6.0$ ), escapes lysosomal degradation, and is released again into the blood. If the blood IgG concentration is high, binding of FcRn to IgG is saturated, then lysosome-mediated IgG degradation is enhanced, and if the IgG concentration is low, IgG is bound to FcRn and recycled, thereby reducing IgG degradation ${ }^{[10]}$.

Gene polymorphism of FcRn has been reported to be involved in FcRn expression, with VNTR of 37 bases occurring in the promoter region ${ }^{[11]}$. The most common VNTR3/VNTR3 homozygous genotype is reported to have 1.66 times more FcRn expression than the VNTR3/VNTR2 heterozygous genotype ${ }^{[1]}$. The levels of anti-TNF-alpha antibodies infliximab and adalimumab are lower in blood by $14 \%$ and $24 \%$, respectively, among heterozygous cases compared to homozygous cases ${ }^{[12]}$. On the other hand, as an antibody drug against cancer, in 94 cases that received cetuximab therapy, which is an EGFR antibody for colorectal cancer, a significant difference in distribution clearance and a tendency to a prolonged half-life were observed. There was no change in PK due to copy number variation (CNV) of FCGRT gene ${ }^{[13]}$. In addition, in 476 patients who received farletuzumab, an anti-folate receptor alpha antibody against ovarian cancer, there was no difference between PK and the area under the curve (AUC) of VNTR genotype and steady-state, and no change in $\mathrm{PK}$ due to $\mathrm{CNV}^{[14]}$. As described above, there are few reports on blood concentrations of antibody drugs against cancer based on the FcRn genotype, and the relationship with efficacy is unknown. Further evidence is needed.

\section{Antibody-dependent cellular cytotoxicity}

An immunoglobulin including an antibody drug binds to an antigen at the Fab region, and the Fc region binds to Fcy Receptor expressed on immune cells in the body. There are six types of Fc $\gamma$ R: I, IIA, IIB, IIC, IIIA, and IIIB. Of them, I, IIA, IIC, IIIA, and IIIB are activated forms, and they mainly activate immune cells by phosphorylation of immunoreceptor tyrosine-based activation motif, which transmits activation signals into cells. On the other hand, IIB causes inhibitory functions via phosphorylation of an immunoreceptor tyrosine-based inhibitory motif ${ }^{[15]}$. The ADCC activity as a mechanism of action of antibody drugs for cancer is considered to be the apoptosis of target cells by the release of perforin and granzyme from NK cells, mainly by the binding of the antibody drug to FcyRIIIA of NK cells. The binding strength of the antibody drug and FcyRIIIA is considered to be correlated with the ADCC activity.

Factors affecting the binding strength to FC $\gamma \mathrm{R}$ include structural problems with the antibody drug and genetic polymorphisms affecting host immunity. Normally, the Fc region of immunoglobulins is glycosylated, and variations with or without terminal galactose, bisecting $\mathrm{N}$-acetylglucosamine, sialic acid, and fucose at the root have been reported. For the ADCC activity, it has been reported that aglycosylation reduces ADCC activity, and addition of bisecting $\mathrm{N}$-acetylglucosamine and removal of fucose increase ADCC activity. It has been reported that the addition of $\mathrm{N}$-acetylglucosamine to mAb increases ADCC activity by $10-20$ times $^{[16]}$. Moreover, fucose removal has undergone many technological developments, such as Potelligent ${ }^{\mathrm{TM}}$ technology (BioWa, Japan) and Glycomab ${ }^{\mathrm{TM}}$ technology (Glycart, Switzerland) based around cell lines engineered with altered glycosylation machinery, that increase ADCC activity by more than $100-$ fold $^{[17,18]}$. In the Potelligent ${ }^{\mathrm{TM}}$ cell line, both FUT8 gene alleles, which encode $\alpha 1,6-$ fucosyltransferase, were disrupted by sequential homologous recombination. The Glycomab ${ }^{\text {TM }}$ cell lines are stably transfected with the gene encoding 1,4-N-acetylglucosaminyltransferse III (GnIII), resulting in the 
Table 3. Fc $\gamma \mathbf{R}$ polymorphisms and antibody drug efficacies

\begin{tabular}{|c|c|c|c|c|c|c|}
\hline Drug & Author (year) & $\begin{array}{l}\text { Disease treatment } \\
(n)\end{array}$ & $\begin{array}{l}\text { FCGR2A-131 } \\
\text { Polymorphism } \\
(n)\end{array}$ & $\begin{array}{l}\text { FCGR3A-158 } \\
\text { Polymorphism } \\
(n)\end{array}$ & $\begin{array}{l}\text { Genotyping } \\
\text { method }\end{array}$ & Results \\
\hline \multirow[t]{5}{*}{ Trastuzumab } & $\begin{array}{l}\text { Musolino et } a l^{[19]} \\
(2008)\end{array}$ & $\begin{array}{l}\text { Metastatic breast } \\
\text { cancer (54) } \\
\text { Trastuzumab + } \\
\text { Taxane }\end{array}$ & $\begin{array}{l}\mathrm{H} / \mathrm{H}(10) \\
\mathrm{H} / \mathrm{R}(34) \\
\mathrm{R} / \mathrm{R}(10)\end{array}$ & $\begin{array}{l}V / V(11) \\
V / F(26) \\
F / F(17)\end{array}$ & $\begin{array}{l}\text { Nested PCR- } \\
\text { based allele- } \\
\text { specific } \\
\text { restriction } \\
\text { analysis assay }\end{array}$ & $\begin{array}{l}\text { FcyRIIla-158 V/V genotype was } \\
\text { significantly correlated with ORR } \\
\text { and PFS. There was a trend to } \\
\text { significance in ORR and PFS for } \\
\text { the FcyRlla- } 131 \mathrm{H} / \mathrm{H} \text { genotype }\end{array}$ \\
\hline & $\begin{array}{l}\text { Tamura et al. }{ }^{[20]} \\
\text { (2011) }\end{array}$ & $\begin{array}{l}\text { Neoadjuvant breast } \\
\text { cancer (15) } \\
\text { AC/ } \\
\text { PTX+Trastuzumab }\end{array}$ & $\begin{array}{l}H / H(7) \\
H / R(6) \\
R / R(2)\end{array}$ & $\begin{array}{l}V / \mathrm{V}(7) \\
V / F(6) \\
F / F(2)\end{array}$ & $\begin{array}{l}\text { Goldgate } \\
\text { Genotyping }\end{array}$ & $\begin{array}{l}\text { The Fc } \gamma R 2 A-131 \mathrm{H} / \mathrm{H} \text { genotype } \\
\text { was significantly correlated } \\
\text { with the } \mathrm{pCR} \text { and the objective } \\
\text { response. The FcyR3A-158 V/V } \\
\text { genotype exhibited a tendency } \\
\text { to be correlated with the } \\
\text { objective response }\end{array}$ \\
\hline & $\begin{array}{l}\text { Tamura et al. }{ }^{[20]} \\
\text { (2011) }\end{array}$ & $\begin{array}{l}\text { Metastatic breast } \\
\text { cancer (35) } \\
\text { Trastuzumab }\end{array}$ & $\begin{array}{l}\mathrm{H} / \mathrm{H}(15) \\
\mathrm{HR}(18) \\
\mathrm{R} / \mathrm{R}(2)\end{array}$ & $\begin{array}{l}V / V(15) \\
V / F(17) \\
F / F(3)\end{array}$ & $\begin{array}{l}\text { Goldgate } \\
\text { Genotyping }\end{array}$ & $\begin{array}{l}\text { Patients with the Fc } \gamma 2 \mathrm{R}-131 \mathrm{H} / \\
\mathrm{H} \text { genotype had significantly } \\
\text { longer PFS }\end{array}$ \\
\hline & $\begin{array}{l}\text { Hurvitz et al. }{ }^{[21]} \\
(2012)\end{array}$ & $\begin{array}{l}\text { Adjuvant breast } \\
\text { cancer (1286) } \\
\text { Trastuzumab } \\
\text { combination }\end{array}$ & $\begin{array}{l}H / H(323) \\
H R(597) \\
R / R(298)\end{array}$ & $\begin{array}{l}V / V(169) \\
V / F(471) \\
F / F(549)\end{array}$ & $\begin{array}{l}\text { Nested PCR } \\
\text { plus Sanger } \\
\text { sequencing }\end{array}$ & $\begin{array}{l}\text { No correlation between DFS and } \\
\text { FCGR3A/2A genotypes was } \\
\text { seen for trastuzumab-treated } \\
\text { patients }\end{array}$ \\
\hline & $\begin{array}{l}\text { Musolino et } a l^{[22]} \\
(2016)\end{array}$ & $\begin{array}{l}\text { Neoadjuvant breast } \\
\text { cancer (73) } \\
\text { Chemotherapy, } \\
\text { Trastuzumab, } \\
\text { Lapatinib. }\end{array}$ & $\begin{array}{l}H / H(101) \\
H R(143) \\
R / R(56)\end{array}$ & $\begin{array}{l}V / V(43) \\
V / F(150) \\
F / F(107)\end{array}$ & $\begin{array}{l}\text { PCR plus Sanger } \\
\text { sequencing }\end{array}$ & 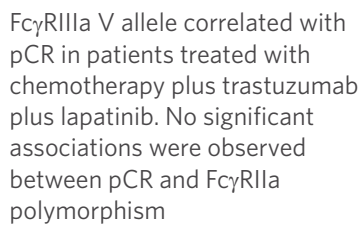 \\
\hline \multirow[t]{8}{*}{ Rituximab } & $\begin{array}{l}\text { Cartron et al. }{ }^{[23]} \\
(2002)\end{array}$ & $\begin{array}{l}\text { Caucasian FL (49) } \\
\text { Rituximab }\end{array}$ & $\begin{array}{l}\mathrm{H} / \mathrm{H}(13) \\
\mathrm{HR}(23) \\
\mathrm{R} / \mathrm{R}(9)\end{array}$ & $\begin{array}{l}V / V(10) \\
V / F(22) \\
F / F(17)\end{array}$ & $\begin{array}{l}\text { PCR followed by } \\
\text { an allele-specific } \\
\text { restriction } \\
\text { enzyme digestion }\end{array}$ & $\begin{array}{l}\text { An association between the } \\
\text { FCGR3A genotype and clinical } \\
\text { and molecular responses to } \\
\text { rituximab }\end{array}$ \\
\hline & $\begin{array}{l}\text { Weng et al. }{ }^{[24]} \\
(2003)\end{array}$ & $\begin{array}{l}\text { Caucasian FL (87) } \\
\text { Rituximab }\end{array}$ & $\begin{array}{l}\mathrm{H} / \mathrm{H}(20) \\
\mathrm{HR}(43) \\
\mathrm{R} / \mathrm{R}(24)\end{array}$ & $\begin{array}{l}V / V(13) \\
V / F(40) \\
F / F(34)\end{array}$ & $\begin{array}{l}\text { Nested PCR } \\
\text { followed by } \\
\text { allele-specific } \\
\text { restriction } \\
\text { enzyme digestion }\end{array}$ & $\begin{array}{l}\text { FcyRIIla } 158 \text { valine/valine and } \\
\text { the FcyRlla } 131 \text { Histidine/ } \\
\text { histidine genotypes were found } \\
\text { to be independently associated } \\
\text { with the response rate and } \\
\text { freedom from progression }\end{array}$ \\
\hline & Kim et al. ${ }^{[25]}$ (2006) & $\begin{array}{l}\text { Asian DLBCL (113) } \\
\text { R-CHOP }\end{array}$ & $\begin{array}{l}\mathrm{H} / \mathrm{H}(60) \\
\mathrm{HR}(40) \\
\mathrm{R} / \mathrm{R}(8)\end{array}$ & $\begin{array}{l}V / V(53) \\
V / F(54) \\
F / F(6)\end{array}$ & $\begin{array}{l}\text { Nested PCR } \\
\text { followed by } \\
\text { allele-specific } \\
\text { restriction } \\
\text { enzyme digestion }\end{array}$ & $\begin{array}{l}\text { No difference was found in OS } \\
\text { or EFS according to FCGR3A or } \\
\text { FCGR2A alleles. The FCGR3A } \\
\text { SNP is predictive of response to } \\
\text { R-CHOP, but does not correlate } \\
\text { with survival }\end{array}$ \\
\hline & $\begin{array}{l}\text { Carlotti et al. }{ }^{[26]} \\
(2007)\end{array}$ & $\begin{array}{l}\text { Caucasian DLBCL } \\
(94) \\
\text { R-CHOP }\end{array}$ & $\begin{array}{l}\mathrm{H} / \mathrm{H}(30) \\
\mathrm{HR}(46) \\
\mathrm{R} / \mathrm{R}(18)\end{array}$ & $\begin{array}{l}V / V(18) \\
V / F(46) \\
F / F(30)\end{array}$ & $\begin{array}{l}\text { PCR with } \\
\text { fluorescent } \\
\text { labeled probes } \\
\text { followed by melt } \\
\text { curve analysis }\end{array}$ & $\begin{array}{l}\text { No correlation between } \\
\text { FcyRIIIA-158VV/VF and FcyRIIA- } \\
131 \mathrm{HH} / \mathrm{HR} \text { polymorphisms and } \\
\text { the OS, response, and the EFS }\end{array}$ \\
\hline & $\begin{array}{l}\text { Mitroviç et al. }{ }^{[27]} \\
(2007)\end{array}$ & $\begin{array}{l}\text { Caucasian DLBCL } \\
(58) \\
\text { R-CHOP }\end{array}$ & $\begin{array}{l}\mathrm{H} / \mathrm{H}(23) \\
\mathrm{HR}(27) \\
\mathrm{R} / \mathrm{R}(8)\end{array}$ & $\begin{array}{l}V / V(16) \\
V / F(32) \\
F / F(10)\end{array}$ & $\begin{array}{l}\text { PCR followed by } \\
\text { allele-specific } \\
\text { restriction } \\
\text { enzyme digestion }\end{array}$ & 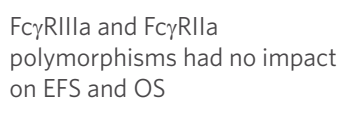 \\
\hline & $\begin{array}{l}\text { Dornan et } a l^{[28]} \\
(2010)\end{array}$ & $\begin{array}{l}\text { Caucasian CLL (419) } \\
\text { Chemotherapy +/- } \\
\text { Rituximab }\end{array}$ & $\begin{array}{l}\mathrm{H} / \mathrm{H}(110) \\
\mathrm{HR}(218) \\
\mathrm{R} / \mathrm{R}(91)\end{array}$ & $\begin{array}{l}V / V(49) \\
V / F(202) \\
F / F(168)\end{array}$ & $\begin{array}{l}\text { Allele-specific } \\
\text { PCR with SYBR } \\
\text { Green }\end{array}$ & $\begin{array}{l}\text { FCGR2A and FCGR3A } \\
\text { polymorphisms do not } \\
\text { significantly influence the } \\
\text { outcomes of CLL patients } \\
\text { treated with chemotherapy }+/- \\
\text { rituximab }\end{array}$ \\
\hline & $\begin{array}{l}\text { Zhang et } a l^{[29]} \\
(2010)\end{array}$ & $\begin{array}{l}\text { Asian DLBCL (34) } \\
\text { R-CHOP }\end{array}$ & NA & $\begin{array}{l}V / V(11) \\
V / F(18) \\
F / F(5)\end{array}$ & $\begin{array}{l}\text { Allele-specific } \\
\text { PCR }\end{array}$ & $\begin{array}{l}\text { FcyRIIIA polymorphisms do not } \\
\text { predict prognosis independently }\end{array}$ \\
\hline & $\begin{array}{l}\text { Prochazka et al. }{ }^{[32]} \\
(2011)\end{array}$ & $\begin{array}{l}\text { Caucasian FL (102) } \\
\text { Rituximab } \\
\text { combination } \\
\text { chemotherapy }\end{array}$ & NA & $\begin{array}{l}V / V(8) \\
V / F(51) \\
F / F(43)\end{array}$ & $\begin{array}{l}\text { Nested PCR } \\
\text { followed by } \\
\text { allele-specific } \\
\text { restriction } \\
\text { enzyme digestion }\end{array}$ & $\begin{array}{l}\text { FcyRIIIA polymorphisms have } \\
\text { no effect on the outcomes } \\
\text { of patients treated with risk- } \\
\text { adapted chemotherapy with or } \\
\text { without rituximab }\end{array}$ \\
\hline
\end{tabular}




\begin{tabular}{|c|c|c|c|c|c|}
\hline $\begin{array}{l}\text { Ahlgrimm et al. } .^{[30]} \\
\text { (2011) }\end{array}$ & $\begin{array}{l}\text { Caucasian DLBCL } \\
\text { (263) }\end{array}$ & $\begin{array}{l}\mathrm{H} / \mathrm{H}(105) \\
\mathrm{HR}(235) \\
\mathrm{R} / \mathrm{R}(64)\end{array}$ & $\begin{array}{l}V / V(76) \\
V / F(140) \\
F / F(47)\end{array}$ & $\begin{array}{l}\text { TaqMAN SNP } \\
\text { Assay }\end{array}$ & $\begin{array}{l}\text { in patients treated with R-CHOP, } \\
\text { the EFS and PFS, but not the } \\
\text { OS, curves for FcyRllla } 158 \mathrm{~F} / \mathrm{F} \\
\text { showed a trend to be lower than } \\
\text { of } 158 \mathrm{~V} / \mathrm{F} \text { and } 158 \mathrm{~V} / \mathrm{V}\end{array}$ \\
\hline $\begin{array}{l}\text { Fabisiewicz et al. }{ }^{[31]} \\
\text { (2011) }\end{array}$ & $\begin{array}{l}\text { Caucasian DLBCL } \\
(87) \\
\text { R-CHOP }\end{array}$ & $\begin{array}{l}\mathrm{H} / \mathrm{H}(27) \\
\mathrm{HR}(40) \\
\mathrm{R} / \mathrm{R}(20)\end{array}$ & $\begin{array}{l}V / V(15) \\
V / F(35) \\
F / F(37)\end{array}$ & $\begin{array}{l}\text { TaqMAN SNP } \\
\text { Assay }\end{array}$ & $\begin{array}{l}\text { Neither FcyRIIA nor FcyRIIIA } \\
\text { allele was statistically } \\
\text { significantly related to OS and } \\
\text { PFS }\end{array}$ \\
\hline $\begin{array}{l}\text { Varoczy et al. }{ }^{[35]} \\
(2012)\end{array}$ & $\begin{array}{l}\text { Caucasian DLBCL } \\
\text { (51) } \\
\text { R-CHOP }\end{array}$ & NA & $\begin{array}{l}V / V(12) \\
V / F(29) \\
F / F(10)\end{array}$ & $\begin{array}{l}\text { TaqMAN SNP } \\
\text { Assay }\end{array}$ & $\begin{array}{l}\text { The EFS data were less favorable } \\
\text { in the F-allele carriers than in } V / \\
\vee \text { homozygous patients, but not } \\
\text { significantly, and OS was almost } \\
\text { the same }\end{array}$ \\
\hline $\begin{array}{l}\text { Ghesquieres et al. }{ }^{[33]} \\
\text { (2012) }\end{array}$ & $\begin{array}{l}\text { Caucasian FL (460) } \\
\text { Rituximab } \\
\text { combination } \\
\text { chemotherapy }\end{array}$ & $\begin{array}{l}\mathrm{H} / \mathrm{H}(127) \\
\mathrm{HR}(226) \\
\mathrm{R} / \mathrm{R}(102)\end{array}$ & $\begin{array}{l}\text { V/V (68) } \\
V / F(215) \\
\text { F/F (177) }\end{array}$ & $\begin{array}{l}\text { TaqMAN SNP } \\
\text { Assay }\end{array}$ & $\begin{array}{l}\text { FCGR3A and FCGR2A } \\
\text { polymorphisms do not affect } \\
\text { response rate and outcome } \\
\text { when rituximab is combined } \\
\text { with chemotherapy or used as } \\
\text { maintenance treatment }\end{array}$ \\
\hline $\begin{array}{l}\text { Persky et al. }{ }^{[34]} \\
(2012)\end{array}$ & $\begin{array}{l}\text { Caucasian FL (142) } \\
\text { Chemotherapy or } \\
\text { Chemotherapy plus } \\
\text { CD20 mAb }\end{array}$ & $\begin{array}{l}\mathrm{H} / \mathrm{H}(17) \\
\mathrm{HR}(40) \\
\mathrm{R} / \mathrm{R}(9)\end{array}$ & $\begin{array}{l}V / V(5) \\
V / F(29) \\
F / F(20)\end{array}$ & $\begin{array}{l}\text { TaqMAN SNP } \\
\text { Assay }\end{array}$ & $\begin{array}{l}\text { FcyRIIIA polymorphism status } \\
\text { may be predictive of survival in } \\
\text { FL patients receiving treatments } \\
\text { containing an anti-CD } 20 \\
\text { antibody but not treatment with } \\
\text { chemotherapy alone }\end{array}$ \\
\hline $\mathrm{Liu}^{[37]}(2014)$ & $\begin{array}{l}\text { Asian DLBCL (164) } \\
\text { R-CHOP }\end{array}$ & & $\begin{array}{l}V / V(14) \\
V / F(59) \\
F / F(91)\end{array}$ & Nested PCR & $\begin{array}{l}\text { FcyRIIIA V/V allele was } \\
\text { borderline significantly } \\
\text { correlated with PFS, but it was } \\
\text { not correlated with better OS }\end{array}$ \\
\hline $\begin{array}{l}\text { Ghesquieres et al. }{ }^{[36]} \\
\text { (2017) }\end{array}$ & $\begin{array}{l}\text { Caucasian DLBCL } \\
\text { (1134) } \\
\text { Rituximab } \\
\text { combination } \\
\text { chemotherapy }\end{array}$ & $\begin{array}{l}\mathrm{H} / \mathrm{H}(289) \\
\mathrm{HR}(579) \\
\mathrm{R} / \mathrm{R}(266)\end{array}$ & $\begin{array}{l}\text { V/V (144) } \\
\text { V/F (513) } \\
\text { F/F (449) }\end{array}$ & $\begin{array}{l}\text { TaqMAN SNP } \\
\text { Assay } \\
\text { Illumina Infinium } \\
\text { array } \\
\text { Pyrosequencing }\end{array}$ & $\begin{array}{l}\text { Meta-analysis of two } \\
\text { prospective studies. } \\
\text { FCGR3A was not associated } \\
\text { with EFS and OS. } \\
\text { FCGR2A (per R allele) was } \\
\text { associated with a better EFS and } \\
\text { OS }\end{array}$ \\
\hline
\end{tabular}

DLBCL: diffuse large B-cell lymphoma; PFS: progression-free survival

expressed antibodies bearing bisecting $\mathrm{N}$-acetylglycosamine. Now, the Potelligent ${ }^{\mathrm{TM}}$ technology is used for the development of mogamulizumab, and the Glycomab ${ }^{\mathrm{TM}}$ technology is used for obinutuzumab.

On the other hand, there are gene polymorphisms of $F c G R$ as a host factor, and among them, polymorphisms of FCGR2A and FCGR3A are reported to be related to ADCC activity. A coding polymorphism in the extracellular domain of FCGR2A has been described where a $\mathrm{C}>\mathrm{T}$ substitution (rs1801274) changes the amino acid at position 131 from histidine to arginine (H131R). A second important $F c G R$ coding polymorphism occurs in extracellular domain 2 of FCGR3A; a T>G substitution changes valine to phenylalanine at position 158 (V158F, rs396991).

Although many studies have been conducted on trastuzumab and rituximab as to whether these gene polymorphisms affect the efficacy of antibody drugs, many conflicting reports have been published [Table 3]. For trastuzumab, FcGR2A H/H and FcGR3A V/V are reported to be correlated with prolongation of progression-free survival (PFS) in metastatic breast cancer, FcGR2A H/H and FcGR3A V/V were reported to be correlated with pathological complete remission in the neo-adjuvant setting, and no obvious correlation was found between FcGR and overall survival in the adjuvant setting; thus, there is still no unified view ${ }^{[19-22]}$. Similarly, rituximab has been investigated for its effect on drug efficacy against follicular lymphoma and diffuse large B cell lymphoma (DLBCL), but there are no reports of statistically significant effects, except in the early $2000 \mathrm{~s}^{[23-37]}$. As described above, FcGR SNPs and the ADCC activity of antibody drugs are clear in vitro, but their relationship with clinical efficacy is not clear. The reasons for this include the validity of the SNP verification method, the possibility that the number of cases needed to verify the effect of SNP 
on ADCC activity has not been collected, and the possibility that there are individual differences in the number or function of host immune cells that exert ADCC activity. The search for further mechanisms and factors involved in ADCC is desirable.

\section{Immune-checkpoint inhibitors}

In recent years, ICIs that activate the exhausted immune cells by inhibiting immune checkpoint molecules typified by CTLA4 and PD-1/PD-L1 pathways with antibody drugs have been key drugs for the treatment of malignant melanoma and non-small cell lung cancer. To date, 1 anti-CTLA4 antibody (ipilimumab), 2 anti-PD- 1 antibodies (nivolumab and pembrolizumab), and 3 anti-PD-L1 antibodies (atezolizumab, durvalumab, and avelumab) have been marketed. Anti-PD-1 antibodies have IgG1 isoforms, and the other ICIs have IgG4 isoforms. All drugs have anti-tumor effects, mainly due to neutralization or signal inhibition, with dramatic therapeutic effects in many cancer types such as malignant melanoma, NSCLC, and merkel cell carcinoma ${ }^{[38]}$. However, ICIs have unclear drug efficacy biomarkers, and they cause immune-related adverse events (irAEs) that are different from the adverse events of conventional anticancer drugs. IrAEs occur due to the activation of host immunity by ICIs, causing immune response disorders and hormonal abnormalities in organs such as the thyroid, lungs, and pancreas. Although myelotoxicity and gastrointestinal toxicity are less likely than with cytotoxic chemotherapy, irAEs can sometimes be life threatening. Moreover, various biomarker searches for PD-1 inhibitors, which are frequently used in clinical practice, have been investigated. Tumor PD-L1 expression, tumor mutation burden (TMB), T cell receptor (TCR) repertoire, human leukocyte antigen (HLA), microbiome, etc. are attracting attention ${ }^{[39]}$. ICIs activate host immunity by blocking the co-stimulatory/inhibitory pathway with antibody drugs, but the major signaling pathway of antigen-presenting cells and $\mathrm{T}$ cells is the binding of major histocompatibility complex (MHC) and TCR. Antigen-presenting cells present peptides produced from tumors as antigens, which are recognized by TCRs. From the above, peptides presented as antigens are factors on the tumor side, and MHC and TCR are factors on the host side.

Tumor antigen peptides that are factors on the tumor side include cancer testis antigens such as the melanoma-associated antigens (MAGEAs) and New York esophageal squamous cell carcinoma 1 that are expressed in tumors regardless of gene mutations, and tumor antigen peptides generated by tumor gene mutations. The number of tumor non-synonymous mutations is called the TMB, and it is attracting attention as an index of tumor immunogenicity, especially in melanoma and NSCLC that typically have high mutation burdens due to the mutagenic effects of ultraviolet light and cigarette smoking, respectively ${ }^{[40]}$. In 2014, Snyder et al ${ }^{[41]}$ performed 64 whole-exome sequencing of melanoma patients treated with CTLA-4 antibody and showed significantly higher TMB in patients with stable or responsive disease for more than 6 months, and TMB more than 100 was associated with better overall survival ${ }^{[41]}$. This result was confirmed by examination of CTLA-4 antibody against other malignant melanoma cohorts, and it was shown that the higher the TMB of non-small cell lung cancer, the better the response rate and PFS of PD-1 antibody ${ }^{[42,43]}$. Since then, many cancer types have been shown to have a linear response rate with TMB, and it has become clear that TMB can help predict certain therapeutic effects ${ }^{[4]}$. However, some cancer types do not follow this linear response. For example, merkel cell carcinoma and renal cell carcinoma are more sensitive than expected to TMB, whereas misamatch-repair (MMR)-proficient colorectal cancer is less sensitive than expected. That is, although TMB has some degree of correlation with the therapeutic effect, other factors are also assumed to be related to the therapeutic effect of ICIs. In addition, technical issues still remain, such as the fact that TMB does not have a confirmed calculation method and cut-off criteria, and whether analysis samples are performed with tumor samples or cell-free DNA.

Like TMB, DNA MMR defects (MMRds) are considered biomarkers of ICIs by causing somatic mutations. Le et al. ${ }^{[45,46]}$ showed that pembrolizumab had a response rate of $53 \%$ in 86 cases with 12 cancer types of 
tumors with MMRds exhibiting micro-satellite instability (MSI), showing a robust efficacy regardless of the type of cancer ${ }^{[45,46]}$. From these results, nivolumab and pembrolizumab were first approved by the FDA in 2017 with the genotype MSI-positive regardless of cancer type.

The HLA genotype is important as a host element. HLA class I is rich in sequence diversity of peptide binding sites. The HLA-I allele is encoded by three genes on chromosome 6 (HLA A, HLA B, and HLA C), and each of these variants constitutes a slightly different peptide. Chowell et al ${ }^{[47]}$ examined the genotype of HLA-I in 1535 patients treated with ICIs. They found that patients with HLA-B44 supertype showed prolonged survival, and patients with HLA-B62 supertype or somatic loss of heterozygosity at HLA-I showed reduced survival ${ }^{[48]}$. Chowell et al. ${ }^{[48]}$ analyzed the expression of MHC class I and II in tumor tissues in malignant melanoma treated with ipilimumab, nivolumab, or their combination. They found that 78 of 181 cases (43\%) showed disappearance of MHC class I, which was correlated with initial tolerance of ipilimumab. In addition, MHC class II expression was observed in 55 of 181 cases (30\%), and a correlation with the therapeutic effect of nivolumab was demonstrated ${ }^{[48]}$.

As described above, several pharmacogenomic factors on the tumor side and host side are attracting attention as ICI efficacy biomarkers. It is difficult to establish a single biomarker for ICIs because there are multiple factors, such as blocking efficiency of the signal pathway and immune environment, on the host side. In particular, the host immune system is considered to be a large factor, and identification of a pharmacogenomic factor that is an index of host immune responsiveness is required.

\section{Antibody-drug conjugate}

Currently, antibody-antibody drugs (ADCs), which are obtained by linking a cytotoxic anticancer drug (called "payload") to the antibody with a linker, have rapidly developed as a new antibody treatment strategy against cancer. The ADC is an innovative drug design approach that increases the local concentration of payload only around the target due to the high target selectivity of antibody drugs (called "bystander effect"). Drugs such as KS1/4-methotrexate and BR96-doxorubicin were developed as the firstgeneration ADCs in the 1980s, but their efficacy was not satisfactory ${ }^{[49,50]}$. This may be due to insufficient titer of the drug itself, wrong target antigen selection, poor internalization efficiency of the antibody, poor tumor accumulation, linker stability too high/low, and immune response to mouse antibodies. Gemtuzumab ozogamicin, an anti-CD33 ADC, received FDA approval for the first time as an ADC product in $2000^{[51]}$. However, subsequent clinical trials found no clinical effect and increased fatal adverse events, and approval was withdrawn ${ }^{[52,53]}$.

In order to overcome the challenges of first-generation ADCs, appropriate target search and appropriate payload development are underway, and brentuximab vedotin (anti-CD30 ADC), ado-trastuzumab emtansine (anti-HER2 ADC), and inotuzumab ozogamicin (anti-CD22 ADC) were approved by the FDA as second-generation $\mathrm{ADCs}^{[54]}$. However, the second-generation ADCs also have problems such as the presence of a few unbound types due to the instability of the linker, early clearance by becoming a free drug, and causing off-target toxicities. The development of these first- and second-generation ADCs showed that selections of appropriate tumor cell targets, payloads, antibodies, linkers, and payload binding sites were important points in drug discovery. In other words, if the appropriate target and an antibody with high binding power cannot be selected, the accumulation of ADC in the tumor will be reduced; if effective payload selection cannot be performed, sufficient cell killing effects cannot be achieved; if the stability of the linker is low, it will dissociate in the body and cause an off-target effect; and if the stability of the linker is too high, an effective bystander effect cannot be attained.

Based on the above, many third-generation ADC products are currently being developed [Table 4]. In particular, in June 2019, the FDA approved Genentech's anti-CD79b ADC, polatuzumab vedotin (Polivy), 
Table 4. Current status of antibody-drug conjugates

\begin{tabular}{|c|c|c|c|c|c|c|c|}
\hline Generic name & $\begin{array}{l}\text { Brand name/ } \\
\text { investigational name }\end{array}$ & Company & Target & Payload & DAR & Major indication & $\begin{array}{l}\text { Current } \\
\text { status }\end{array}$ \\
\hline Brentuximab vedotin & Adcetris & $\begin{array}{l}\text { Seattle Genetics/ } \\
\text { Takeda }\end{array}$ & CD30 & MMAE & 4 & Hodgkin lymphoma & Approved \\
\hline $\begin{array}{l}\text { Gemtuzumab } \\
\text { ozogamicin }\end{array}$ & Mylotarg & Pfizer & CD33 & Calicheamicins & 3 & Acute myeloid leukemia & Approved \\
\hline Trastuzumab emtansine & Kadcyla & Roche & HER2 & DM1 & 3.5 & Breast cancer & Approved \\
\hline Inotuzumab ozogamicin & Besponsa & Pfizer & CD22 & Calicheamicins & NR & $\begin{array}{l}\text { Acute B-cell } \\
\text { lymphoblastic leukemia }\end{array}$ & Approved \\
\hline Polatuzumab vedotin & Polivy & Genentech & CD79b & MMAE & 3.5 & DLBCL & Approved \\
\hline Telisotuzumab vedotin & ABBV-399 & AbbVie & c-Met & MMAE & 3.1 & NSCLC, solid tumor & Phase 2 \\
\hline Samrotamab vedotin & ABBV-085 & AbbVie & LRRC15 & MMAE & 2 & Sarcoma, HNCC, Breast & Phase 1 \\
\hline $\begin{array}{l}\text { Trastuzumab } \\
\text { deruxtecan }\end{array}$ & DS-8201a & Daiichi Sankyo & HER2 & DXd & 8 & Breast, Lung, Colon & Phase 3 \\
\hline- & DS-1062a & Daiichi Sankyo & Trop2 & DXd & 4 & Solid tumor & Phase 1 \\
\hline- & U3-1402 & Daiichi Sankyo & HER3 & DXd & 8 & Breast, Lung & Phase 1 \\
\hline- & MORAB-202 & Eisai & FOLR1 & Eribulin & 4 & Solid tumor & Phase 1 \\
\hline Enfortumab vedotin & ASG-22CE & $\begin{array}{l}\text { Astellas pharma/ } \\
\text { Seattle genetics }\end{array}$ & Nectin-4 & MMAE & NR & Urothelial & Phase 3 \\
\hline Tisotumab vedotin & HuMax-TF & $\begin{array}{l}\text { Genmab/Seattle } \\
\text { Genetics }\end{array}$ & $\mathrm{TF}$ & MMAE & NR & Solid tumor, Cervical & Phase 2 \\
\hline Enapotamab vedotin & $\begin{array}{l}\text { HuMax-AXL- } \\
\text { ADC }\end{array}$ & $\begin{array}{l}\text { Genmab/Seattle } \\
\text { genetics }\end{array}$ & $A X L$ & MMAE & NR & Solid tumor & Phase 1/2 \\
\hline Ladiratuzumab vedotin & SGN-LIV1A & Seattle genetics & LIV-1 & MMAE & NR & Lung, Breast & Phase 2 \\
\hline $\begin{array}{l}\text { Mirvetuximab } \\
\text { soravtansine }\end{array}$ & IMGN853 & ImmunoGen & FOLR1 & DM4 & NR & $\begin{array}{l}\text { FOLR1 positive solid } \\
\text { tumor }\end{array}$ & Phase 3 \\
\hline Sacituzumab govitecan & IMMU-132 & Immunomedics & Trop2 & SN38 & 7.5 & $\begin{array}{l}\text { Breast, Urothelial, } \\
\text { Glioblastoma }\end{array}$ & Phase 3 \\
\hline- & XMT-1536 & $\begin{array}{l}\text { Mersana } \\
\text { Therapeutics }\end{array}$ & $\mathrm{NaPi} 2 \mathrm{~b}$ & AF-HPA & $\sim 12$ & Ovary, NSCLC & Phase 1 \\
\hline- & SAR408701 & Sanofi & CEACAM5 & DM4 & NR & Solid tumor & Phase 1 \\
\hline
\end{tabular}

MMAE: monomethyl auristatin E; AF-HPA: austatin F-HPA; DXd: exatecan derivative; NR: not reported

for relapsed/refractory DLBCL. This drug showed the surprising result that complete remission was obtained in $40 \%(16 / 40)$ in the polatuzumab vedotin and bendamustine plus rituzimab therapy group in the Phase $1 \mathrm{~b} / 2$ trial $\left(\mathrm{GO} 29365\right.$ study ${ }^{[55]}$. Currently, clinical trials are ongoing with hematological tumors such as follicular lymphoma and in combination with other drugs ${ }^{[56]}$. Moreover, Daiichi Sankyo's novel antiHER2 ADC, Ds8201a (Trastuzumab Deruxtecan), is under development. In breast cancer, multiple phase 3 studies for patients with HER2-positive cancer (DESTINY-Breast01: NCT03248492, DESTINY-Breast02: NCT03523585, DESTINY-Breast03: NCT03529110), a phase 3 study for HER2-low cancer (DESTINYBreast04: NCT03734029), a phase 2 study for HER2-positive gastric (DESTINY-Gastric01: NCT03329690), lung (NCT03505710), and colon cancers (NCT03384940), and combined use with ICIs (NCT04042701, NCT03523572) are in progress. A recently reported Phase 1 trial for HER2-positive advanced breast cancer showed a surprising response rate of 59.5\% despite a previous heavy treatment history with trastuzumab or $\mathrm{T}-\mathrm{DM}{ }^{[57]}$. On the other hand, as an adverse event, pneumonitis was reported in 20 cases, and 2 fatal cases also occurred. Currently, the FDA has granted Fast Track and Breakthrough Therapy designations, and early approval is expected.

As shown in Table 4, there are currently 14 ADCs showing relatively good progress. Each drug targets not only HER2, but also HER3, Trop2, FOLR1, c-Met, AXL, and other molecules that are specifically expressed in tumors. Of 14 ADCs, 10 drugs used tubulin inhibitors (including 6 MMAE, 2 Maytansinoid DM4, 1 Eribulin, and 1 AF-HPA), and 4 drugs used a DNA topoisomerase I inhibitor (3 DXd, 1 SN38). In previous generations of ADCs, tubulin inhibitors were used in about $60 \%$ or more of payloads, but ADCs using a topoisomerase I inhibitor are increasing. In addition to improving the payload, each company is improving 
the drug-antibody ratio, the stability of the linker, and the cancer cell specificity, which have been issues with ADCs. In addition to the development of ADCs alone, their combination with ICIs is being actively developed.

Although it is expected that there will be a wider range of options for antibody therapy, the pharmacogenomic factors in ADCs are not clear so far. Since the antibody part is IgG1 in many ADCs, the above-mentioned Fc $\gamma$ R polymorphism may have an effect. There is also concern about the effects of metabolic and excretory enzymes in the payload. For example, there are reports that ABCC1 overexpression is involved in drug resistance to trastuzumab emtanisine, and that $\mathrm{ABCB} 1$ is associated with the efficacy of gemtuzumab ozogamicin ${ }^{[58,59]}$. In addition, MMAE, frequently used as a payload in many $\mathrm{ADCs}$, is a CYP3A4 substrate, and eribulin is also a CYP3A4 substrate and an $\mathrm{ABCB} 1$ substrate. In other words, classical pharmacogenomic factors such as $\mathrm{ABC}$ transporter and CYP may affect metabolism and excretion of payloads and thus drug efficacy even in ADCs.

Moreover, recent ADC adverse events in clinical trials raise new concerns about immunogenicity. It has been reported that Ds8201a has a high incidence of pneumonitis, and this was the same case with Morab-202, which showed pneumonitis in 3 of 19 cases $(15.8 \%)^{[60]}$. Since the frequency of pneumonitis is not high with antibody drugs alone, pneumonitis may be a characteristic adverse event of ADCs. It is desirable to examine the pharmacogenomic factors of ADCs that are expected to be used more frequently in the future, including the enhancement of immunogenicity due to the linkage between linker and payload, and the possibility of affecting the responsiveness of host immunity.

As described above, ADCs have developed rapidly in recent years, but pharmacogenomic factors have not been fully studied. In addition to analyzing classical ABC transporters and CYP polymorphisms, pharmacogenomic analyses including host factors for characteristic adverse events such as lung injury are greatly needed.

\section{FUTURE DIRECTION OF RESEARCH}

There are still many black boxes in the pharmacokinetics of antibody drugs. Despite confirming doses several tens of times for the target occupancy in preclinical research, antibody blood concentrations in clinical practice may vary widely. Until now, it has been said that the pharmacokinetics of antibody drugs are not related to renal function, liver function or metabolic pathway, however, increased catabolism associated with organ dysfunction may affect the pharmacokinetics of antibody drugs. Furthermore, it is not clear whether the blood concentration of antibody drugs is correlated with the intratumoral concentration. It is necessary to identify the detailed pharmacokinetics of antibody drugs and the factors that affect the pharmacokinetics.

Another issue that must be considered is biosimilars. Unlike generic drugs, biosimilars cannot prove the identity of active ingredients. Therefore, at the time of approval, structural similarity is shown in a comparative quality study, PD and toxicity are shown in a comparative preclinical study, and PK, safety and efficacy are confirmed in a comparative clinical study. However, comparative clinical trials are only specifically designed to rule out clinically relevant differences in safety or efficacy between the biosimilar and the reference medicine, and to confirm biosimilarity. Differences in sugar chain modification and activity between lots have also been pointed out in the previous products, and it is still unclear whether biosimilars can exhibit sufficient pharmacokinetics and antitumor effects in clinical practice ${ }^{[61]}$. In addition, it will be necessary to verify immunogenicity and pharmacogenomic differences. 


\section{CONCLUSION}

The pharmacogenomics of antibody drugs is a complex area with more relevant factors than small molecule compounds. It is expected that pharmacogenomic factors related to drug efficacy and adverse events will be identified by comprehensively analyzing not only PK and PD, but also multiple factors such as host immune environment and genetic factors.

\section{DECLARATIONS}

\section{Authors' contributions}

Wrote the manuscript and prepared the figures and tables: Yagishita S, Hamada A

\section{Availability of data and materials}

Not applicable.

\section{Financial support and sponsorship}

None.

\section{Conflicts of interest}

Both authors declared that there are no conflicts of interest.

\section{Ethical approval and consent to participate}

Not applicable.

\section{Consent for publication}

Not applicable.

\section{Copyright}

(c) The Author(s) 2019.

\section{REFERENCES}

1. Frazer JK, Capra JD. Immunoglobulins: structure and function. Fundamental Immunology. 4th edition. New York: Lippincott-Raven; 1999. pp. 37-74.

2. Köhler G, Milstein C. Continuous cultures of fused cells secreting antibody of predefined specificity. Nature 1975;256:495-7.

3. Smith KG, Clatworthy MR. FcgammaRIIB in autoimmunity and infection: evolutionary and therapeutic implications. Nat Rev Immunol 2010;10:328-43.

4. Undevia SD, Gomez-Abuin G, Ratain MJ. Pharmacokinetic variability of anticancer agents. Nat Rev Cancer 2005;5:447-58.

5. Liu L. Pharmacokinetics of monoclonal antibodies and Fc-fusion proteins. Protein Cell 2018;9:15-32.

6. Brambell FW, Hemmings WA, Morris IG. A theoretical model of gamma-globulin catabolism. Nature 1964;203:1352-4.

7. Brambell FW. The transmission of immunity from mother to young and the catabolism of immunoglobulins. Lancet 1966;2:1087-93.

8. Simister NE, Mostov KE. Cloning and expression of the neonatal rat intestinal Fc receptor, a major histocompatibility complex class I antigen homolog. Cold Spring Harb Symp Quant Biol 1989;54 Pt 1:571-80.

9. Akilesh S, Christianson GJ, Roopenian DC, Shaw AS. Neonatal FcR expression in bone marrow-derived cells functions to protect serum IgG from catabolism. J Immunol 2007;179:4580-8.

10. Roopenian DC, Akilesh S. FcRn: the neonatal Fc receptor comes of age. Nat Rev Immunol 2007;7:715-25.

11. Sachs UJ, Socher I, Braeunlich CG, Kroll H, Bein G, et al. A variable number of tandem repeats polymorphism influences the transcriptional activity of the neonatal Fc receptor alpha-chain promoter. Immunology 2006;119:83-9.

12. Billiet T, Dreesen E, Cleynen I, Wollants WJ, Ferrante M, et al. A genetic variation in the neonatal Fc-receptor affects anti-TNF drug concentrations in inflammatory bowel disease. Am J Gastroenterol 2016;111:1438-45.

13. Passot C, Azzopardi N, Renault S, Baroukh N, Arnoult C, et al. Influence of FCGRT gene polymorphisms on pharmacokinetics of therapeutic antibodies. MAbs 2013;5:614-9.

14. O'Shannessy DJ, Bendas K, Schweizer C, Wang W, Albone E, et al. Correlation of FCGRT genomic structure with serum immunoglobulin, albumin and farletuzumab pharmacokinetics in patients with first relapsed ovarian cancer. Genomics 2017;109:251-7.

15. Kaifu T, Nakamura A. Polymorphisms of immunoglobulin receptors and the effects on clinical outcome in cancer immunotherapy and other immune diseases: a general review. Int Immunol 2017;29:319-25.

16. Umana P, Jean-Mairet J, Moudry R, Amstutz H, Bailey JE. Engineered glycoforms of an antineuroblastoma IgG1 with optimized antibody- 
dependent cellular cytotoxic activity. Nat Biotechnol 1999;17:176-80.

17. Kirin K. Poteligent technology. Available from: https://www.kyowakirin.com/biowa/out-licensing/technologies/index.html. [Last accessed on 6 Nov 2019]

18. GlycoMAb technology. Available from: https://www.roche.ch/en/standorte/schlieren/schlieren_about_glycomab.htm. [Last accessed on 6 Nov 2019]

19. Musolino A, Naldi N, Bortesi B, Pezzuolo D, Capelletti M, et al. Immunoglobulin G fragment C receptor polymorphisms and clinical efficacy of trastuzumab-based therapy in patients with HER-2/neu-positive metastatic breast cancer. J Clin Oncol 2008;26:1789-96.

20. Tamura K, Shimizu C, Hojo T, Akashi-Tanaka S, Kinoshita T, et al. FcgammaR2A and 3A polymorphisms predict clinical outcome of trastuzumab in both neoadjuvant and metastatic settings in patients with HER2-positive breast cancer. Ann Oncol 2011;22:1302-7.

21. Hurvitz SA, Betting DJ, Stern HM, Quinaux E, Stinson J, et al. Analysis of Fegamma receptor IIIa and IIa polymorphisms: lack of correlation with outcome in trastuzumab-treated breast cancer patients. Clin Cancer Res 2012;18:3478-86.

22. Musolino A, Naldi N, Dieci MV, Zanoni D, Rimanti A, et al. Immunoglobulin G fragment C receptor polymorphisms and efficacy of preoperative chemotherapy plus trastuzumab and lapatinib in HER2-positive breast cancer. Pharmacogenomics J 2016;16:472-7.

23. Cartron G, Dacheux L, Salles G, Solal-Celigny P, Bardos P, et al. Therapeutic activity of humanized anti-CD20 monoclonal antibody and polymorphism in IgG Fc receptor FcgammaRIIIa gene. Blood 2002;99:754-8.

24. Weng WK, Levy R. Two immunoglobulin G fragment C receptor polymorphisms independently predict response to rituximab in patients with follicular lymphoma. J Clin Oncol 2003;21:3940-7.

25. Kim DH, Jung HD, Kim JG, Lee JJ, Yang DH, et al. FCGR3A gene polymorphisms may correlate with response to frontline R-CHOP therapy for diffuse large B-cell lymphoma. Blood 2006;108:2720-5.

26. Carlotti E, Palumbo GA, Oldani E, Tibullo D, Salmoiraghi S, et al. FegammaRIIIA and FegammaRIIA polymorphisms do not predict clinical outcome of follicular non-Hodgkin's lymphoma patients treated with sequential CHOP and rituximab. Haematologica 2007;92:1127-30.

27. Mitroviç Z, Aurer I, Radman I, Ajdukovic R, Sertic J, et al. FCgammaRIIIA and FCgammaRIIA polymorphisms are not associated with response to rituximab and CHOP in patients with diffuse large B-cell lymphoma. Haematologica 2007;92:998-9.

28. Dornan D, Spleiss O, Yeh RF, Duchateau-Nguyen G, Dufour A, et al. Effect of FCGR2A and FCGR3A variants on CLL outcome. Blood 2010;116:4212-22.

29. Zhang W, Wang X, Li J, Duan MH, Zhou DB. Fegamma receptor IIIA polymorphisms and efficacy of rituximab therapy on Chinese diffuse large B-cell lymphoma. Chin Med J (Engl) 2010;123:198-202.

30. Ahlgrimm M, Pfreundschuh M, Kreuz M, Regitz E, Preuss KD, et al. The impact of Fc-gamma receptor polymorphisms in elderly patients with diffuse large B-cell lymphoma treated with CHOP with or without rituximab. Blood 2011;118:4657-62.

31. Fabisiewicz A, Paszkiewicz-Kozik E, Osowiecki M, Walewski J, Siedlecki JA. FcgammaRIIA and FcgammaRIIIA polymorphisms do not influence survival and response to rituximab, cyclophosphamide, doxorubicin, vincristine, and prednisone immunochemotherapy in patients with diffuse large B-cell lymphoma. Leuk Lymphoma 2011;52:1604-6.

32. Prochazka V, Papajik T, Gazdova J, Divoka M, Rozmanova S, et al. FcyRIIIA receptor genotype does not influence an outcome in patients with follicular lymphoma treated with risk-adapted immunochemotherapy. Neoplasma 2011;58:263-70.

33. Ghesquieres H, Cartron G, Seymour JF, Delfau-Larue MH, Offner F, et al. Clinical outcome of patients with follicular lymphoma receiving chemoimmunotherapy in the PRIMA study is not affected by FCGR3A and FCGR2A polymorphisms. Blood 2012;120:2650-7.

34. Persky DO, Dornan D, Goldman BH, Braziel RM, Fisher RI, et al. Fe gamma receptor 3a genotype predicts overall survival in follicular lymphoma patients treated on SWOG trials with combined monoclonal antibody plus chemotherapy but not chemotherapy alone. Haematologica 2012;97:937-42.

35. Varoczy L, Zilahi E, Gyetvai A, Kajtar B, Gergely L, et al. Fc-gamma-receptor IIIa polymorphism and gene expression profile do not predict the prognosis in diffuse large B-cell lymphoma treated with R-CHOP protocol. Pathol Oncol Res 2012;18:43-8.

36. Ghesquieres H, Larrabee BR, Haioun C, Link BK, Verney A, et al. FCGR3A/2A polymorphisms and diffuse large B-cell lymphoma outcome treated with immunochemotherapy: a meta-analysis on 1134 patients from two prospective cohorts. Hematol Oncol 2017;35:447-55.

37. Liu F, Ding H, Jin X, Ding N, Deng L, He Y, Zhu J, Song Y. FCGR3A 158V/F polymorphism and response to frontline R-CHOP therapy in diffuse large B-cell lymphoma. DNA Cell Biol 2014;33:616-23.

38. Gong J, Chehrazi-Raffle A, Reddi S, Salgia R. Development of PD-1 and PD-L1 inhibitors as a form of cancer immunotherapy: a comprehensive review of registration trials and future considerations. J Immunother Cancer 2018;6:8.

39. Havel JJ, Chowell D, Chan TA. The evolving landscape of biomarkers for checkpoint inhibitor immunotherapy. Nat Rev Cancer 2019;19:133-50.

40. Alexandrov LB, Nik-Zainal S, Wedge DC, Aparicio SA, Behjati S, et al. Signatures of mutational processes in human cancer. Nature 2013;500:415-21.

41. Snyder A, Makarov V, Merghoub T, Yuan J, Zaretsky JM, et al. Genetic basis for clinical response to CTLA-4 blockade in melanoma. N Engl J Med 2014;371:2189-99.

42. Rizvi NA, Hellmann MD, Snyder A, Kvistborg P, Makarov V, et al. Cancer immunology. Mutational landscape determines sensitivity to PD-1 blockade in non-small cell lung cancer. Science 2015;348:124-8.

43. Van Allen EM, Miao D, Schilling B, Shukla SA, Blank C, et al. Genomic correlates of response to CTLA-4 blockade in metastatic melanoma. Science 2015;350:207-11.

44. Yarchoan M, Hopkins A, Jaffee EM. Tumor mutational Burden and response rate to PD-1 inhibition. N Engl J Med 2017;377:2500-1.

45. Le DT, Uram JN, Wang H, Bartlett BR, Kemberling H, et al. PD-1 blockade in tumors with mismatch-repair deficiency. N Engl J Med 2015;372:2509-20.

46. Le DT, Durham JN, Smith KN, Wang H, Bartlett BR, et al. Mismatch repair deficiency predicts response of solid tumors to PD-1 blockade. Science 2017;357:409-13. 
47. Chowell D, Morris LGT, Grigg CM, Weber JK, Samstein RM, et al. Patient HLA class I genotype influences cancer response to checkpoint blockade immunotherapy. Science 2018;359:582-7.

48. Rodig SJ, Gusenleitner D, Jackson DG, Gjini E, Giobbie-Hurder A, et al. MHC proteins confer differential sensitivity to CTLA-4 and PD-1 blockade in untreated metastatic melanoma. Sci Transl Med 2018;10:eaar3342.

49. Elias DJ, Hirschowitz L, Kline LE, Kroener JF, Dillman RO, et al. Phase I clinical comparative study of monoclonal antibody KS1/4 and KS1/4-methotrexate immunconjugate in patients with non-small cell lung carcinoma. Cancer Res 1990;50:4154-9.

50. Trail PA, Willner D, Lasch SJ, Henderson AJ, Hofstead S, et al. Cure of xenografted human carcinomas by BR96-doxorubicin immunoconjugates. Science 1993;261:212-5.

51. Sievers EL, Linenberger M. Mylotarg: antibody-targeted chemotherapy comes of age. Curr Opin Oncol 2001;13:522-7.

52. Ravandi F. Gemtuzumab ozogamicin: one size does not fit all--the case for personalized therapy. J Clin Oncol 2011;29:349-51

53. Panowski S, Bhakta S, Raab H, Polakis P, Junutula JR. Site-specific antibody drug conjugates for cancer therapy. MAbs 2014;6:34-45.

54. Dosio F, Brusa P, Cattel L. Immunotoxins and anticancer drug conjugate assemblies: the role of the linkage between components. Toxins (Basel) 2011;3:848-83.

55. Sehn LH, Herrera AF, Matasar MJ, Kamdar MK, McMillan A, et al. Addition of Polatuzumab Vedotin to Bendamustine and Rituximab (BR) improves outcomes in transplant-ineligible patients with relapsed/refractory (R/R) diffuse large B-cell lymphoma (DLBCL) versus BR alone: results from a randomized phase 2 study. Blood 2017;130:2821.

56. Deeks ED. Polatuzumab vedotin: first global approval. Drugs 2019;79:1467-75.

57. Tamura K, Tsurutani J, Takahashi S, Iwata H, Krop IE, et al. Trastuzumab deruxtecan (DS-8201a) in patients with advanced HER2-positive breast cancer previously treated with trastuzumab emtansine: a dose-expansion, phase 1 study. Lancet Oncol 2019;20:816-26.

58. Cianfriglia M. The biology of MDR1-P-glycoprotein (MDR1-Pgp) in designing functional antibody drug conjugates (ADCs): the experience of gemtuzumab ozogamicin. Ann Ist Super Sanita 2013;49:150-68.

59. Loganzo F, Tan X, Sung M, Jin G, Myers JS, et al. Tumor cells chronically treated with a trastuzumab-maytansinoid antibody-drug conjugate develop varied resistance mechanisms but respond to alternate treatments. Mol Cancer Ther 2015;14:952-63.

60. Shimizu T, Fujiwara Y, Yonemori K, Koyama T, Shimomura A, et al. First-in-human (FIH) phase 1 (Ph1) study of MORAb-202 in patients (pts) with advanced folate receptor alpha (FRA)-positive solid tumors. J Clin Oncol 2019;37:5544.

61. Kim S, Song J, Park S, Ham S, Paek K, et al. Drifts in ADCC-related quality attributes of Herceptin(R): impact on development of a trastuzumab biosimilar. MAbs 2017;9:704-14. 